Article

\title{
Cereus sinensis Polysaccharide and Its Immunomodulatory Properties in Human Monocytic Cells
}

\author{
Junwen Wu, Xuefei Zhou, Min Zhang, Yun Yao, Juanjuan Han and Kehai Liu* \\ Department of Biopharmaceutics, College of Food Science and Technology, Shanghai Ocean University, \\ Shanghai 201306, China; 15800711801@163.com (J.W.); zhouxuefeibest@163.com (X.Z.); \\ 13122223561@163.com (M.Z.); m150208413@st.shou.edu.cn (Y.Y.); jjhan1409@163.com (J.H.) \\ * Correspondence: khliu@shou.edu.cn; Tel.: +86-156-9216-5857 \\ Academic Editors: Paul Long, Orazio Taglialatela-Scafati and Alejandro M. Mayer \\ Received: 16 March 2017; Accepted: 4 May 2017; Published: 18 May 2017
}

\begin{abstract}
In this study, the extraction conditions of the crude polysaccharide from Cereus sinensis were optimized by response surface methodology. The optimum extraction conditions were: a ratio of raw material to water volume of $1: 80(\mathrm{~g} / \mathrm{mL})$; an extraction temperature of $72{ }^{\circ} \mathrm{C}$; and an extraction time of $3 \mathrm{~h}$. Then, a purified polysaccharide named Cereus sinensis polysaccharide-1 (CSP-1) was obtained from the crude polysaccharide by the Diethylaminoethyl cellulose-52 (DEAE-52) cellulose chromatography column and Sephadex G-100 column. The molecular weight and monosaccharide composition of CSP-1 was determined through Gel Permeation Chromatography (GPC) and Gas Chromatography-Mass Spectrometer (GS-MS), respectively. The results showed that CSP-1 with an average molecular weight of 56,335 Da was composed of L-(-)-Fucose, D-(+)-Mannose, D-Glucose and mainly possessed $1 \rightarrow 2,1 \rightarrow 2,6,1 \rightarrow 4$, and $1 \rightarrow 4,6$ of glycosyl linkages. The immunomodulatory activities of CSP-1 were also evaluated using lipopolysaccharide (LPS)-induced human monocytic (THP-1) cells. The results demonstrated that CSP-1 dose-dependently protected against LPS-induced toxicity, and CSP-1 significantly inhibited the Toll-like receptor 4 (TLR-4) mRNA, myeloid differentiation factor 88 (MyD88) mRNA and tumour necrosis factor receptor-associated factor-6 (TRAF-6) mRNA expression of the LPS-induced THP-1 cells, as well as suppressing reactive oxygen species (ROS) generation.
\end{abstract}

Keywords: Cereus sinensis; polysaccharide; THP-1 cells; immunomodulatory property

\section{Introduction}

Marine organisms grew in the special environment of high salinity, high pressure, hypothermia, low light and oligotrophic qualities. As a result, the polysaccharides originating from marine organisms exhibited a unique structure and showed good prospects with immune regulation, anti-inflammation, anticoagulation, anti-virus, anti-tumor and so on [1]. Based on the origins, the polysaccharides were classified into three types: seaweed polysaccharides, marine microbial polysaccharides and marine animal polysaccharides [2]. At present, compared with marine animal polysaccharides, the research on seaweed polysaccharides and marine microbial polysaccharides were richer and more mature. In recent years, with the further development of marine resources, marine animal polysaccharides present unique properties, including good biocompatibility with human cells, low toxic side effects and significant physiological activities such as anti-tumor, anti-virus, anti-aging, anti-blood sugar, anticoagulant and so on $[1,3,4]$, more and more attention has been focused on marine animal polysaccharides. For example, the polysaccharide from purple sea urchin shells showed anti-inflammatory activity by inhibiting RAW264.7 cell growth and releasing NO production [5], 
and a polysaccharide isolated from Meretrix meretrix Linnaeus presented immunological activity [6]. Previous studies also have demonstrated that Cyclina sinensis, Hyriopsis cumingii and other marine animal polysaccharides have exhibited anticancer activity [7].

As a marine animal, it has been recorded that sea anemone (Coelenterata, Anthozoa, Actiniaria) possess many pharmaceutical properties, including antitumor $[8,9]$, antihypertensive, antibacterial, analgesic, and anti-inflammatory [10]. At the same time, sea anemone as a food has been accepted by more and more people. So far, attention has mainly been paid to polypeptides, proteins, the toxins structure and the field of biological activity of sea anemone; however, there are rarely studies done on polysaccharides of sea anemone [11,12]. The chemical components of Zoanthus stephensoni growing in the Xisha Islands of the South China Sea were studied by Zheng for the first time. Meanwhile, the polysaccharides extracted from these sea anemones were obviously effective in lowering blood pressure $[13,14]$.

Cereus sinensis belongs to Actiniaria, Hormathiidae Carlgren, Calliactis Verrill [15], which is widely distributed in coastal waters of the Pacific and China's Yellow Sea, Bohai Sea, East Sea, South Sea and so on. Furthermore, there are not currently not many studies on Cereus sinensis. For instance, the cytolytic toxins were preliminarily isolated from Cereus sinensis Verrill, the factors influencing cytolytic toxins were investigated [16], and the analysis on nutrients and non-volatile tastecompounds of Cereus sinensis was carried out [17]. However, the research on Cereus sinensis polysaccharides and their biological activities has not been reported. In this study, we investigated the partial characterization of a purified polysaccharide CSP-1 isolated from Cereus sinensis and evaluated its immunomodulatory activites in vitro.

\section{Results}

\subsection{Optimization of the Polysaccharide Extraction}

The polysaccharide of Cereus sinensis was extracted through "the hot water extraction and alcohol precipitation" method, which was optimized by response surface methodology. The three parameters (the solid:liquid ratio, the extraction temperature and the extraction time) were investigated in this experiment (Table 1). As a result, the optimum extraction condition of Cereus sinensis polysaccharide is a ratio of raw material to water volume of $1: 80(\mathrm{~g} / \mathrm{mL})$, an extraction temperature of $72{ }^{\circ} \mathrm{C}$ and an extraction time of $3 \mathrm{~h}$ (Table 2).

Table 1. Experimental design and results of response surface methodology.

\begin{tabular}{ccccc}
\hline Number & Solid:Liquid Ratio $(\mathbf{g} / \mathbf{m L})$ & Time $(\mathbf{h})$ & Temperature $\left({ }^{\circ} \mathbf{C}\right)$ & Extraction Yield (\%) \\
\hline 1 & $1: 90$ & 3 & 60 & 21.22 \\
2 & $1: 80$ & 2 & 60 & 18.67 \\
3 & $1: 90$ & 4 & 70 & 23.20 \\
4 & $1: 70$ & 3 & 80 & 21.05 \\
5 & $1: 80$ & 4 & 80 & 22.15 \\
6 & $1: 80$ & 4 & 60 & 22.30 \\
7 & $1: 70$ & 3 & 60 & 20.20 \\
8 & $1: 80$ & 3 & 70 & 23.80 \\
9 & $1: 80$ & 3 & 70 & 23.76 \\
10 & $1: 80$ & 3 & 70 & 23.80 \\
11 & $1: 80$ & 3 & 70 & 23.78 \\
12 & $1: 90$ & 3 & 80 & 23.34 \\
13 & $1: 70$ & 2 & 70 & 20.05 \\
14 & $1: 80$ & 2 & 80 & 22.05 \\
15 & $1: 70$ & 4 & 70 & 20.98 \\
16 & $1: 80$ & 3 & 70 & 24.50 \\
17 & $1: 90$ & 2 & 70 & 20.45 \\
\hline
\end{tabular}


Table 2. Variance analysis and significance test.

\begin{tabular}{ccccccc}
\hline Source & Sum of Square & df & Mean Square & F Value & Prob $>$ F & Significance \\
\hline Model & 44.85 & 9 & 4.98 & 72.93 & $<0.0001$ & significant \\
A-Solid:liquid ratio $(\mathrm{g} / \mathrm{mL})$ & 4.4 & 1 & 4.4 & 64.32 & $<0.0001$ & \\
B-Time $(\mathrm{h})$ & 6.86 & 1 & 6.86 & 100.44 & $<0.0001$ & \\
C-Temperature $\left({ }^{\circ} \mathrm{C}\right)$ & 4.81 & 1 & 4.8 & 70.31 & $<0.0001$ & \\
$\mathrm{AB}$ & 0.83 & 1 & 0.83 & 12.12 & 0.0103 & \\
$\mathrm{AC}$ & 0.4 & 1 & 0.4 & 5.9 & 0.0455 & \\
$\mathrm{BC}$ & 3.12 & 1 & 3.12 & 45.59 & 0.0003 & \\
$\mathrm{~A}^{2}$ & 7.1 & 1 & 7.1 & 103.97 & $<0.0001$ & \\
$\mathrm{~B}^{2}$ & 8.96 & 1 & 8.96 & 131.16 & $<0.0001$ & \\
$\mathrm{C}^{2}$ & 5.83 & 1 & 5.83 & 85.28 & $<0.0001$ & \\
Residual & 0.48 & 7 & 0.068 & & & \\
Lack of fit & 0.068 & 3 & 0.023 & 0.22 & 0.8767 & not significant \\
Pure error & 0.41 & 4 & 0.1 & & & \\
Cor total & 45.33 & 16 & & & &
\end{tabular}

\subsection{Isolation and Purification of Polysaccharide}

Polysaccharide isolated from Cereus sinensis was first eluted through a DEAE-52 (Diethylaminoethyl cellulose) anion-exchange column to yield one peak (Figure 1a). The elution product was collected, dialyzed and lyophilized to obtain a polysaccharide named CPS. CPS was further purified by a Sephadex G-100 column. The elution curve was shown in Figure 1b. The elution product was collected, dialyzed and lyophilized to obtain a purified polysaccharide named CPS-1.

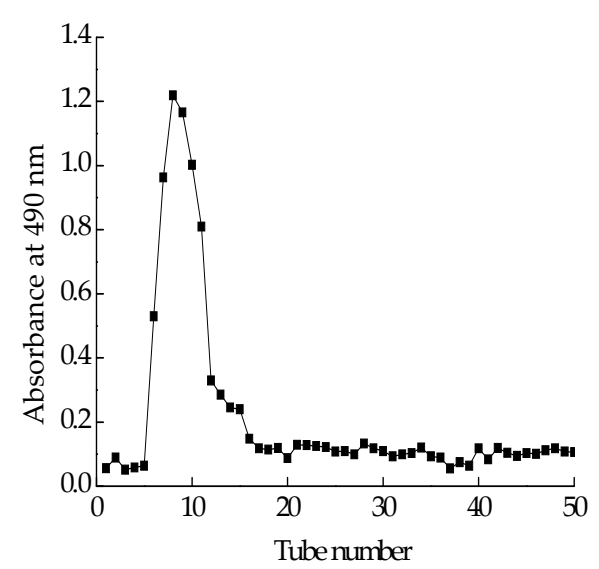

(a)

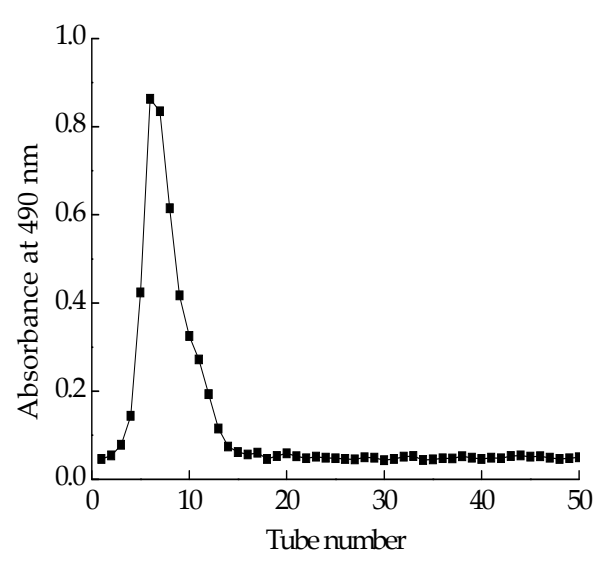

(b)

Figure 1. Purification of polysaccharide: (a) elution profile of crude polysaccharide extracted from Cereus sinensis on a DEAE-52 (Diethylaminoethyl cellulose) anion-exchange column; (b) elution profile of fraction from A on Sephadex G-100 column.

\subsection{Molecular Weight and Monosaccharide Composition of CPS-1}

Gel Permeation Chromatography (GPC) was applied to determine the average molecular weight (MW) of CSP-1, using polyethylene glycol (PEG) as the standard to establish the calibration curve. The result indicated that its average molecular weight was $56335 \mathrm{Da}$ (Table 3). The monosaccharide composition of CSP-1 was analyzed by Chromatography-Mass Spectrometer (GC-MS). The result showed that CSP-1was composed of L-(-)-Fucose, D-(+)-Mannose, and D-Glucose (Table 4). 
Table 3. GPC analysis of CSP-1. Mn: Number-average molecular weight; $\mathrm{M}_{\mathrm{W}}$ : Weight-average molecular weight; $M_{P}$ : Peak molecular weight; $M_{Z}$ : Z-average molecular weight; $M_{Z}+1: Z+1$-average molecular weight.

\begin{tabular}{cccccccc}
\hline Dist Name & Retention Time (min) & Adjusted RT (min) & $\mathbf{M n}$ & $\mathbf{M}_{\mathbf{W}}$ & $\mathbf{M}_{\mathbf{P}}$ & $\mathbf{M}_{\mathbf{Z}}$ & $\mathbf{M}_{\mathbf{Z}}+\mathbf{1}$ \\
\hline 28.228 & 28.228 & 2505 & 56,335 & 3937 & 263,586 & 691,260 \\
\hline
\end{tabular}

Table 4. GC-MS analysis of CSP-1.

\begin{tabular}{ccccccc}
\hline \multicolumn{1}{c}{ Name } & Retention Time & Type & Peak Width & Peak Area & Starting Time & End Time \\
\hline L-(-)-Fucose & 12.4 & BB & 0.048 & $13,501,531$ & 12.219 & 12.489 \\
D-(+)-Mannose & 15.342 & BV & 0.04 & $1,077,806$ & 15.203 & 15.4 \\
D-glucose & 15.488 & VB & 0.042 & 904,727 & 15.4 & 15.562 \\
\hline
\end{tabular}

\subsection{Periodate Oxidation of CSP-1}

The results showed that $0.963 \mathrm{~mol}$ of periodate was consumed per mole of sugar and $0.127 \mathrm{~mol}$ formic acid was produced. The formation of formic acid suggested the presence of pyranohexose in $1 \rightarrow$ or $1 \rightarrow 6$ linked forms in $12.7 \%$. As the amount of periodate consumption was more than twofold the amount of formic acid produced, linkages that only consumed periodate without formic acid production were therefore deduced to exist as $1 \rightarrow 2,1 \rightarrow 2,6,1 \rightarrow 4$, and $1 \rightarrow 4,6$ forms, which occupied $70.9 \%$ of the total glycosyl linkages. The ratio of other linkages as $1 \rightarrow 3$-linked forms was $16.4 \%$, which did not consume periodate.

\subsection{Effects of CPS-1 on Cell Viability}

As shown in Figure 2, the effect of CSP-1 on lipopolysaccharide (LPS)-induced human monocytic (THP-1) cell viability was investigated. Results showed that CSP-1 concentration-dependantly prevented LPS-induced toxicity in the THP-1 cells. When the concentration was achieved at $10 \mu \mathrm{g} / \mathrm{mL}$ or more, CSP-1 was able to protect the THP-1 cells against LPS-induced toxicity. Thus, CSP-1 at this concentration was selected for further studies of immunomodulatory properties.

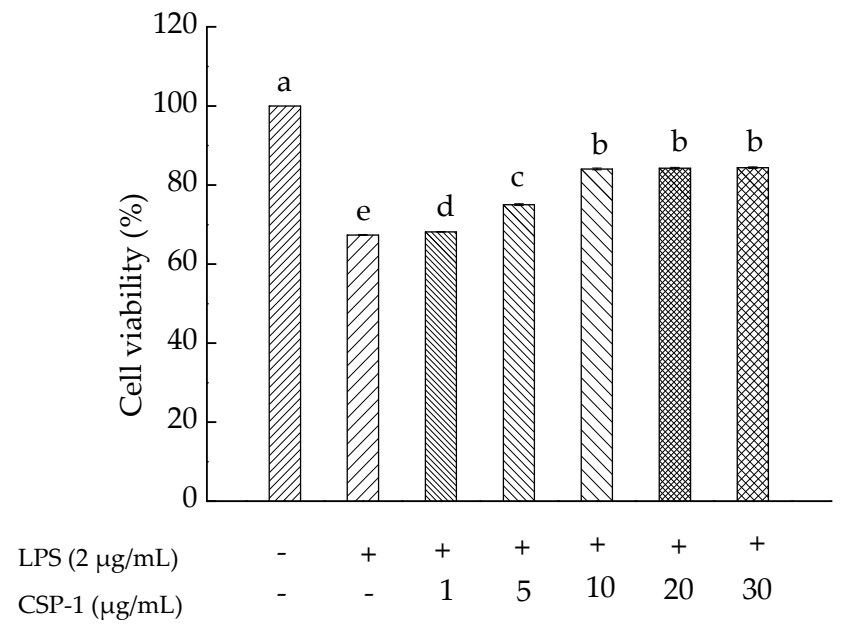

Figure 2. Influences of Cereus sinensis polysaccharide on cell viability. Cells were treated with LPS $(2 \mu \mathrm{g} / \mathrm{mL})$ for $24 \mathrm{~h}$ in the absence or presence of CSP-1 at different concentrations $(1,5,10,20$ and $30 \mu \mathrm{g} / \mathrm{mL}$ ). MTT (3-(4,5-dimethylthiazol-2-yl)-2,5-diphenyltetrazolium bromide) assay was conducted to measure cell viability. Values are mean $\pm \mathrm{SD}$ (standard deviation) $(n=3)$; bars with the same letter being accepted, suggesting no significant differences between groups when the value of $p$ was $<0.05$ in accordance with Duncan's multiple range test. "-" and "+" denotes no addition and addition of sample, respectively. 


\subsection{CPS-1 Inhibited the LPS-Induced ROS Formation}

Exposure of THP-1 cells to LPS $(1 \mu \mathrm{g} / \mathrm{mL})$ alone resulted in increasing the mean fluorescence intensity observably, from $58.63 \pm 1.12$ (a.u) to $92.25 \pm 2.89$ (a.u). However, CSP-1 $(10 \mu \mathrm{g} / \mathrm{mL})$ treatment caused the fluorescence intensity to decrease to $60.76 \pm 3.58$ (a.u) in LPS-stimulated cells (Figure 3). These results demonstrated that LPS $(1 \mu \mathrm{g} / \mathrm{mL})$ treatment gave rise to a significant increase in ROS level, but CSP-1 treatment $(10 \mu \mathrm{g} / \mathrm{mL})$ significantly stopped the ROS generation in LPS-stimulated THP-1 cells.

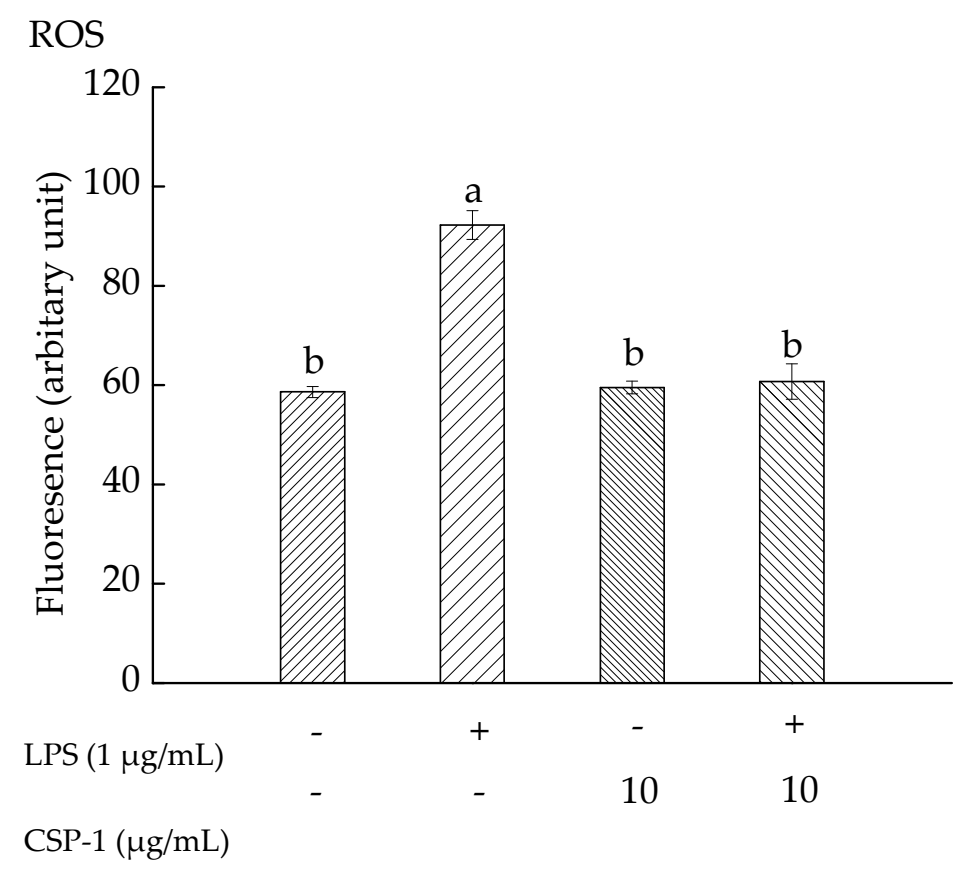

Figure 3. Influences of CSP-1 on reactive oxygen species (ROS) generation. Cells were treated with LPS $(1 \mu \mathrm{g} / \mathrm{mL})$ for $24 \mathrm{~h}$ in the absence or presence of CSP-1 $(10 \mu \mathrm{g} / \mathrm{mL})$, followed by adding $10 \mu \mathrm{M}$ DCFH-DA to incubate for $30 \mathrm{~min}$. Values are mean $\pm \mathrm{SD}(n=3)$; bars with the same letter were accepted as suggesting no significant differences between groups when value of $p$ was $<0.05$ in accordance with Duncan's multiple range test. "-" and "+" denotes no addition and addition of sample, respectively.

\subsection{PSCPL Influenced the TLR-4, MyD88 and TRAF-6 Signal Transduction Pathways}

As shown in Figure 4a, compared with the un-treated cells, Toll-like receptor (TLR-4) mRNA expression of the cells with LPS treatment reduced significantly. Furthermore, simultaneous exposure of LPS and CSP-1 showed a remarkable difference in the expression of TLR-4 mRNA from those treated with LPS alone. The results suggested that CSP-1 could downregulate the expression of TLR- 4 mRNA in LPS-stimulated THP-1 cells.

As showed in Figure 4b, MyD88 mRNA expression of the THP-1 cells increased significantly as a result of LPS treatment. However, CSP-1 treatment led to remarkable reduction of MyD88 mRNA expression in LPS-induced THP-1 cells, which indicated that CSP-1 could downregulate the MyD88 mRNA expression of the LPS-induced THP-1 cells.

As showed in Figure 4c, TRAF-6 mRNA expression of the THP-1 cells showed no difference from those treated with LPS only. When CSP-1 was added to the LPS-stimulated THP-1 cells, the expression of Tumour necrosis factor receptor-associated factor (TRAF-6) mRNA declined observably. This demonstrated that the TRAF-6 mRNA expression of the LPS-induced THP-1 cells might be downregulated with CPS-1 treatment. 

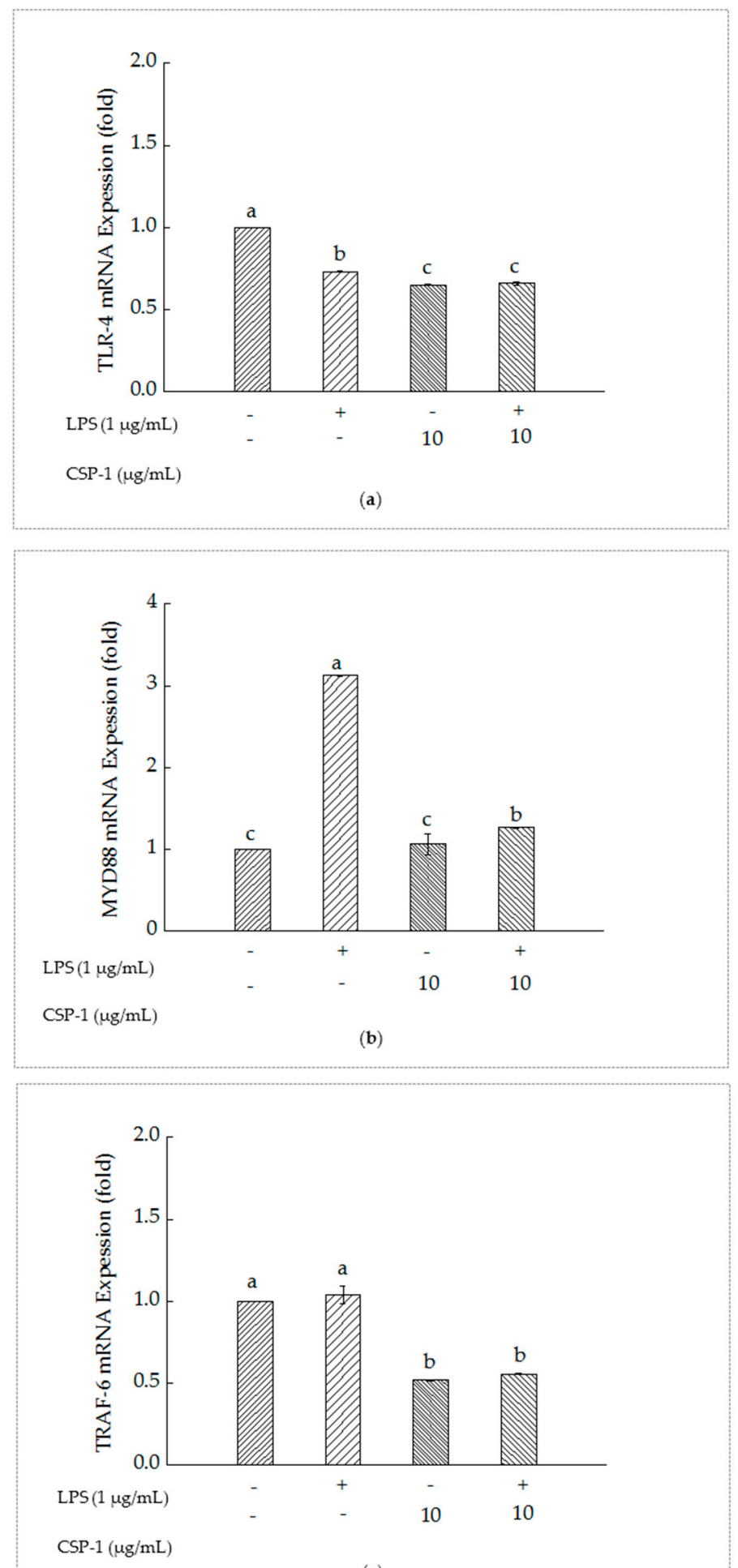

(c)

Figure 4. Influences of CSP-1 on TLR-4 mRNA (a), MyD88 mRNA (b) and TRAF-6 mRNA (c) expression. Cells were stimulated with LPS $(1 \mu \mathrm{g} / \mathrm{mL})$ for $24 \mathrm{~h}$ in the absence or presence of CSP-1 $(10 \mu \mathrm{g} / \mathrm{mL})$. Total RNA was extracted and the content of gene expression was determined by real-time RT-PCR. Values are mean $\pm \mathrm{SD}(n=3)$; bars with the same letter were accepted as suggesting no significant differences between groups when value of $p$ was $<0.05$ in accordance with Duncan's multiple range test. 


\section{Discussion}

In this study, the polysaccharide was isolated and purified from Cereus sinensis for the first time and the immunomodulatory activity was investigated using LPS-induced THP-1 cells. The effect of CSP-1 on RAW264.7 cells had already been investigated using alamar blue assay, and results showed that CSP-1 $(1-30 \mu \mathrm{g} / \mathrm{mL})$ exhibited no cytotoxicity to these cells. The experiment demonstrated that CSP-1 $(10 \mu \mathrm{g} / \mathrm{mL}$ or more) could protect THP-1 cells against LPS-stimulated toxicity. The ROS generation, TLR-4 mRNA expression, MyD88 mRNA expression and TRAF- 6 mRNA expression of LPS-induced THP-1 cells were significantly inhibited by adding $10 \mu \mathrm{g} / \mathrm{mL}$ CSP-1. A polysaccharide from sea anemone has been reported to possess immune activity in vitro. For example, the polysaccharide isolated from Edwardsia ipunculoides exhibited immune activity by promoting the concentration of TNF- $\alpha$ in THP-1 cells [12]. TNF- $\alpha$ is a cytokine produced by foreign antigen stimulated-macrophages, which can directly kill most of the tumor cells, as well as promoting wound healing, angiogenesis and other effects [18,19].

Exposure of THP- 1 cells to LPS resulted in activation of the TLR-4, which led to the activation of signaling cascades, including MyD88 and TRAF-6 [20]. At the same time, it was proposed that simultaneous exposure of THP-1 cells to LPS and compounds, combined with gene expression analysis, was a useful in vitro screening tool to select inflammation modulating compounds [21]. Furthermore, previous studies showed that chronic inflammatory diseases could be treated effectively by modulating TLR signaling pathways [22,23]. Astragalus polysaccharide inhibited LPS-induced cardiomyocyte hypertrophy in rats through the TLR4/NF-KB (nuclear factor) signal transduction [24]. The dysregulation of TLR-4 signaling pathway had a close relationship with development and progress of various diseases, such as nephrotic syndrome, nephritis, renal insufficiency, hypothyroidism [25], systemic lupus erythematosus [26], diabetes [27] and so on. As a result, we investigated the effects of CSP-1 on LPS/TLR-4 signal pathways and the adaptor protein of this signal pathway in THP-1 cells, including MyD88 and TRAF-6, to explore its immunomodulatory mechanism. In our study, CSP-1 treatment downregulated TLR-4 mRNA expression in LPS-stimulated THP-1 cells. Inhibition of TLR-4 expression was a kind of negative regulator for TLR-4 signaling [28]. Quantitative RT-PCR and luciferase reporter gene experiments confirmed that the expression of TLR-4 was inhibited after miRNA lethal-7i at post-transcriptional level interacted with the $3^{\prime}$-untranslated region of TLR-4 mRNA $[29,30]$. It was possible that inhibition of TLR-4 mRNA expression linked to TLR-4 expression suppression. The MyD88-dependent pathway belonged to TLR-4 signaling [20]. MyD88 was an immediate adaptor molecule, which was recruited by activated TLR-4, and was critical for triggering the activation of signaling cascades, including IRAK-1(interleukin receptor) and IRAK-4 [31,32]. MyD88 formed a complex with TLR-4, IRAK1, and IRAK-4, and then IRAK1 was phosphorylated and separated from the complex $[33,34]$. TRAF- 6 was another adaptor protein that was recruited and activated by phosphorylated IRAK1 and played an essential role in activating transforming growth (TAK1) [20]. Subsequently, TAK1 recruited and activated the complex of NF-KB and inhibitor of nuclear factor (IKK). Hereafter, Inhibitor of nuclear factor kappa B (IкB) was phosphorylated, ubiquitinated and degradated. It led to NF- $\kappa B$ separating from I $\mathrm{KB}$ and entering the nucleus, followed by initiating or enhancing the inflammatory genes transcription and promoting expression of inflammatory factors and inflammatory chemokines, such as tumor necrosis factor- $\alpha$ (TNF- $\alpha$ ) and Interleukin-12 (IL-12) [35,36]. TAK1 also activated the mitogen-activated protein kinase (MAPK) signaling pathway, which led to the activation of subgroups extracellular signal-regulated kinase (ERK), p38 mitogen-activated protein kinase and C-jun n-terminal kinase (JNK), followed by formation of transcription factor activator protein-1 (AP-1), regulation of IL-1, IL-6 and TNF- $\alpha$ and other inflammatory factors of transcription in the end $[37,38]$. Consistent with the effects of Phellinus linteus polysaccharides on LPS-stimulated THP-1 cells [39], CSP-1 treatment significantly inhibited ROS generation and led to downregulation of MyD88 mRNA and TRAF-6 mRNA expression in LPS-induced THP-1 cells. It was probable that expression of MyD88 mRNA and TRAF-6 mRNA decreased in the MyD88-dependent signaling pathway and 
ROS generation reduced in the TLR-4/NADPH oxidase/ROS signaling pathway as a result of TLR-4 signaling transduction weakening by inhibition of TLR-4 expression.

ROS was indispensable for activation of NF- $\mathrm{KB}$ and MAPKs [40]. It was reported that the increase of ROS production was a prerequisite for the activation of p38 MAPK in LPS-stimulated cardiomyocytes [41]. In addition, Wu showed that suppression of LPS-induced ROS generation with PSCPL treatment resulted in repressing the downstream signals of the TLR-4 pathways, such as cytokine production, NF- $\mathrm{kB}$ p65 activation, and so on [39]. In this study, ROS generation was suppressed by CSP-1, which might also attenuate the downstream signal in the TLR-4 signaling pathway.

It had been reported that attenuating TLR-4 signaling was a potential effective therapy for coronary artery disease [29], and the inhibition of the ROS generation, expression of TLR-4 mRNA, MyD88 mRNA and TRAF-6 mRNA in LPS-stimulated THP-1 cells with CSP-1 treatment is strong evidence for its potential immunomodulatory activities.

\section{Materials and Methods}

\subsection{Samples and Materials}

Cereus sinensis was purchased from Taizhou, Zhejiang Province, China. Roswell Park Memorial Institute (RPMI) 1640 medium and fetal bovine serum (FBS) were purchased from Invitrogen (Carlsbad, CA, USA). Lipopolysaccharide (LPS), 3-(4,5-dimethylthiazol-2-yl)-2,5-diphenyl tetrazolium bromide (MTT), dimethyl sulfoxide (DMSO), 2', $7^{\prime}$-dichlorofluorescin diacetate (DCFH-DA) and buffered solution (PBS) were purchased from Sigma-Aldrich (St. Louis, MO, USA). Sodium chloride, hydrochloric acid, sodium hydroxide, ethanol, acetone, pyridine, acetic anhydride trichloroacetic acid, trifluoroacetic acid (TFA), hydroxylamine hydrochloride, sodium periodate, ethylene glycol, phenolphthalein and trichloromethane were bought from Sinopharm Chemical Reagent Co., Ltd. (Shanghai, China).

\subsection{Sample Preparation, Isolation and Purification of the Polysaccharide}

Fresh sea anemones were soaked in $2 \% \mathrm{NaCl}$ solution for two days to remove impurities. Then, the water of sea anemones surface was wiped with absorbent paper. Subsequently, the sea anemones were homogenized, followed by addition of equal volume acetone (overnight) to remove fats. After filtering with gauze, the residue was freeze-dried, sealed in the Ziploc bag and stored in the refrigerator at $-20^{\circ} \mathrm{C}$. The response surface methodology was used to get the optimal extraction conditions of the crude polysaccharide from Cereus sinensis according to Table 1.

Degreased sea anemone powder was extracted with distilled water (1:80 solid/liquidratio) for $3 \mathrm{~h}$ at $72{ }^{\circ} \mathrm{C}$. Then, the aqueous extracts were filtered twice and precipitated with three fold $95 \%$ $(v / v)$ ethanol for 2 days at room temperature. Subsequently, the mixture was centrifuged at $4000 \mathrm{rpm}$ for $20 \mathrm{~min}$ at $4{ }^{\circ} \mathrm{C}$ and precipitation was dried at $60{ }^{\circ} \mathrm{C}$ in constant temperature drying oven to obtain the Cereus sinensis crude polysaccharide. The crude polysaccharide $(5 \mathrm{~g})$ was dissolved in $100 \mathrm{~mL}$ distilled water; hereafter, supernatant was collected by centrifugation at $4000 \mathrm{rpm}$ for $20 \mathrm{~min}$ at $4{ }^{\circ} \mathrm{C}$ and deproteinised by addition of $3 \%(\mathrm{~m} / \mathrm{v})$ trichloroacetic acid to a final concentration of $20 \%(v / v)$ overnight at $4{ }^{\circ} \mathrm{C}$. After removal of the protein, the mixture was concentrated by rotator evaporator $\left(50 \mathrm{rpm} 60^{\circ} \mathrm{C}\right.$ ) and dialyzed (3500D MWCO) against ultrapure water for 2 days and then freeze-dried $(24 \mathrm{~h})$ to yield the polysaccharide. Furthermore, $20 \mathrm{mg} / \mathrm{mL}$ polysaccharide solution $(5 \mathrm{~mL})$ was prepared and loaded onto a DEAE- 52 cellulose chromatography column, and washed with water, followed by a linear gradient elution with an $\mathrm{NaCl}$ solution $(0.1,0.3 \mathrm{~mol} / \mathrm{L})$ at a flow rate of $0.5 \mathrm{~mL} / \mathrm{min}$. The polysaccharide content was determined by testing the absorbance of each fraction $(6 \mathrm{~mL})$ at $490 \mathrm{~nm}$ according to the phenol-sulfuric acid method. The fraction containing polysaccharide was combined, concentrated, dialyzed (3500D MWCO) and lyophilized. This polysaccharide was further purified by a Sephadex G-100 column, and eluted with $0.1 \mathrm{~mol} / \mathrm{L} \mathrm{NaCl}$ at a flow rate of 
$0.5 \mathrm{~mL} / \mathrm{min}$ to yield a single peak (Figure $1 \mathrm{~b}$ ). The fraction was collected, concentrated, dialyzed (3500D MWCO) and lyophilized to get a purified polysaccharide.

\subsection{Determination of the Molecular Weight of Polysaccharide}

The molecular weight of polysaccharide was determined by GPC (Waters 2695 GPC, Manchester, UK), using three GPC columns of HR3, HR4 and HR5 column $(7.8 \mathrm{~mm} \times 300 \mathrm{~mm})$, and a Waters 2414 refractive index detector. A fifty microliter sample was injected, and mobile phase consisting of PBS and $\mathrm{NaN}_{3}$ was used at a flow rate of $1 \mathrm{~mL} / \mathrm{min}$. Column temperature was set as $40{ }^{\circ} \mathrm{C}$ and operation time was $45 \mathrm{~min}$. PEG was used as standard sample and established standard curve.

\subsection{Analysis of Monosaccharide Composition}

The monosaccharide composition of CSP-1 was detected using GS-MS. Furthermore, $10 \mu \mathrm{g}$ CSP-1 was accurately weighed, and then $2 \mathrm{~mL}$ TFA $(2 \mathrm{~mol} / \mathrm{L})$ was added to a sealed round-bottomed flask to hydrolyze in a $100{ }^{\circ} \mathrm{C}$ water bath for $6 \mathrm{~h}$. Subsequently, the TFA was completely removed by rotating and evaporating at $40{ }^{\circ} \mathrm{C}$ under reduced pressure. The hydrolyzate was dissolved in $0.5 \mathrm{~mL}$ pyridine and reacted in a $90^{\circ} \mathrm{C}$ water bath for $30 \mathrm{~min}$ with successive shaking after adding $10.0 \mathrm{mg}$ hydroxylamine hydrochloride. After cooling to room temperature, $0.5 \mathrm{~mL}$ acetic anhydride was added and reacted in a $90{ }^{\circ} \mathrm{C}$ water bath for another $30 \mathrm{~min}$ with shaking. After cooling to room temperature, the solution was rotated and evaporated at $50{ }^{\circ} \mathrm{C}$ under reduced pressure. Hereafter, $1 \mathrm{~mL}$ chloroform was added and centrifuged at $4000 \mathrm{rpm}$ for $5 \mathrm{~min}$ to obtain a supernatant for GS-MS analysis. The analysis was performed on an Agilent 7890A gas chromatograph (Agilent Technologies, Little Fall, NY, USA)equipped with a DB-5MS column $(30 \mathrm{~m} \times 0.25 \mathrm{~mm} \times 0.25 \mu \mathrm{m})$ coupled with an Agilent 5975C mass spectrometer (Agilent Technologies, Little Fall, NY, USA). Eight monosaccharide standards (D-Glucose, D-(+)-Mannose, L-(+)-Rhamnose, D-(+)-Galactose, D-Xylose, L-(-)-Fucose, D-Allose and DL-Arabinose) were prepared using the same method. The operation was performed under the following procedure: injection temperature: $270{ }^{\circ} \mathrm{C}$; injection volume: $1.0 \mu \mathrm{L}$; column temperature programmed as: $100^{\circ} \mathrm{C}$ for $5 \mathrm{~min}$, and then increased to $190{ }^{\circ} \mathrm{C}$ at $20^{\circ} \mathrm{C} / \mathrm{min}$, $260{ }^{\circ} \mathrm{C}$ at $3{ }^{\circ} \mathrm{C} / \mathrm{min}$, and finally $300{ }^{\circ} \mathrm{C}$ at $10{ }^{\circ} \mathrm{C} / \mathrm{min}$ keeping for $5 \mathrm{~min} ; \mathrm{He}(99.999 \%): 1.0 \mathrm{~mL} / \mathrm{min}$; no shunt; interface temperature: $270{ }^{\circ} \mathrm{C}$; ion source temperature: $230{ }^{\circ} \mathrm{C}$; four pole temperature: $150{ }^{\circ} \mathrm{C}$; electron bombardment source: $70 \mathrm{eV}$; electron multiplier: $2153 \mathrm{~V}$; scanning range: 33-550 amu; National Insititute of Standards and Technology (NIST) library.

\subsection{Periodate Oxidation}

In addition, $30 \mathrm{mg}$ of CSP-1 was oxidized with $30 \mathrm{~mL} 15 \mathrm{mmol} / \mathrm{L} \mathrm{NaIO}_{4}$ and kept in the dark for nearly $48 \mathrm{~h}$ at $4{ }^{\circ} \mathrm{C}$. The absorbance was measured at $223 \mathrm{~nm}$ every $6 \mathrm{~h}$ until the consumption of $\mathrm{NaIO}_{4}$ reached a constant value. Subsequently, ethylene glycol $(1 \mathrm{~mL})$ was added to samples $(2 \mathrm{~mL})$ to prevent the reaction. The amount of formic acid produced was titrated with $5 \mathrm{mmol} / \mathrm{L} \mathrm{NaOH}$.

\subsection{Cell Culture}

THP-1 was obtained from the cell bank of the Chinese Academy of Science (Shanghai, China). Cells were cultured in RPMI- 1640 medium with $10 \%$ heat-inactivated FBS and incubated at $37^{\circ} \mathrm{C}$ in a humidified $5 \% \mathrm{CO}_{2}$ atmosphere.

\subsection{MTT Assay}

The cytotoxicity of polysaccharide was measured by MTT assay. THP-1 cells were distributed to each well of a 96-well plate for $24 \mathrm{~h}$ and each well contained $100 \mu \mathrm{L}$ cell suspension. Furthermore, $100 \mu \mathrm{L}$ serum-free media with final concentrations of the $2 \mu \mathrm{g} / \mathrm{mL}$ LPS or $2 \mu \mathrm{g} / \mathrm{mL}$ LPS plus $1 \mu \mathrm{g} / \mathrm{mL}$, $5 \mu \mathrm{g} / \mathrm{mL}, 10 \mu \mathrm{g} / \mathrm{mL}, 20 \mu \mathrm{g} / \mathrm{mL}$, and $30 \mu \mathrm{g} / \mathrm{mL}$ of CPS-1 were added to each cell well, respectively. After incubating the plate for $24 \mathrm{~h}$ with $5 \% \mathrm{CO}_{2}$ at $37^{\circ} \mathrm{C}$, cells were collected by centrifugation at 
$1000 \mathrm{rpm}$ for $5 \mathrm{~min}$ and washed with buffered solution (PBS) before adding $20 \mu \mathrm{L} 5 \mathrm{mg} / \mathrm{mL}$ sterilized MTT solution and $180 \mu \mathrm{L}$ of fresh growth medium, and kept at $37^{\circ} \mathrm{C}$ for $4 \mathrm{~h}$. Subsequently, the MTT/growth medium was removed by centrifugation at $1000 \mathrm{rpm}$ for $5 \mathrm{~min}$, replaced by $150 \mu \mathrm{L}$ DMSO and kept for 10 min with gentle vortexing at room temperature to dissolve blue formazan formed by living cells. The absorbance value was measured at $570 \mathrm{~nm}$ with a microplate reader.

\subsection{Intracellular ROS Assay}

THP-1 cells were distributed to a 24-well plate for $24 \mathrm{~h}$ and each well contained $900 \mu \mathrm{L}$ cell suspension. Then, $100 \mu \mathrm{L}$ serum-free media with final concentrations of the $1 \mu \mathrm{g} / \mathrm{mL} \mathrm{LPS}, 10 \mu \mathrm{g} / \mathrm{mL}$ CPS- 1 or $1 \mu \mathrm{g} / \mathrm{mL}$ LPS plus $10 \mu \mathrm{g} / \mathrm{mL}$ CPS- 1 were added to each cell well, respectively. After incubating the plate for $24 \mathrm{~h}$ with $5 \% \mathrm{CO}_{2}$ at $37^{\circ} \mathrm{C}$, cells were collected by centrifugation at $1000 \mathrm{rpm}$ for $5 \mathrm{~min}$ and washed with PBS. Subsequently, cells were treated with $10 \mu \mathrm{M}$ of DCFH-DA and then incubated in the dark for $30 \mathrm{~min}$ with $5 \% \mathrm{CO}_{2}$ at $37{ }^{\circ} \mathrm{C}$. At last, cells were washed with PBS twice and placed on ice to be tested by flow cytometry.

\subsection{Quantitative Reverse Transcriptase Polymerase Chain Reaction (RT-PCR) Analysis}

Total RNA from THP-1 cell was isolated using RNAiso Plus Code NO. 9108/9109, TaKaRa Bio Inc., Dalian, Liaonin, China). Subsequently, total RNA was reverse transcribed to cDNA using PrimeScript ${ }^{\mathrm{TM}}$ RT reagent Kit with gDNA Eraser (Code NO. PR047A, TaKaRa Bio Inc., Dalian, Liaonin, China). The Applied Biosystems 7500 Real Time PCR System (Applied Biosystems, Foster City, CA, USA) was applied to quantify the relative content of mRNA. The PCR conditions of initial denaturation were 1 rep at $95^{\circ} \mathrm{C}$ for $30 \mathrm{~s}$, followed by 40 reps at $95^{\circ} \mathrm{C}$ for $5 \mathrm{~s}, 60^{\circ} \mathrm{C}$ for $34 \mathrm{~s}$, and 1 rep at $95^{\circ} \mathrm{C}$ for $15 \mathrm{~s}$, $60^{\circ} \mathrm{C}$ for $1 \mathrm{~min}$, and $95^{\circ} \mathrm{C}$ for $15 \mathrm{~s}$. The primers used were human GAPDH sense primer, $5^{\prime}$-AAA TCC CAT CAC CAT CTT CC-3'; antisense primer, 5'-GCA GAG ATG ATG ACC CTT T-3'; human TLR-4 sense primer, 5'-ATG CCT GTG CTG AGT TT-3'; antisense primer, 5'-CTC TAC CAT ACT TTA TGC AGC C- $3^{\prime}$; human MyD88 sense primer, $5^{\prime}$-CTA GGT GGG AAA GTC CCA TCA-30'; antisense primer, $5^{\prime}$-TCT TCC TCT CTC TGT GCT TCA TTA-3'; and human TRAF- 6 sense primer, $5^{\prime}$-TCC TTG CCC TGTTCT CAA T-3'; and antisense primer, 5'-GCA TGG AAC GTG TGGAT-3'.

\subsection{Data Statistics}

Data were expressed as mean \pm standard deviation (SD) of three repeated experiments. SPSS Statistics 17.0 (SPSS, Chicago, IL, USA) was used to calculate values according to one way analysis of variance (ANOVA) and Duncan's multiple range tests. $p$-value of less 0.05 was considered to be significantly different.

\section{Conclusions}

In this paper, the optimal extraction conditions of Cereus sinensis polysaccharide were investigated using response surface methodology and three parameters (ratio of material to liquid, extraction temperature and extraction time) were studied. The results showed that the optimum extraction condition was as follows: a ratio of material to water volume of 1:80 $(\mathrm{g} / \mathrm{mL})$; extraction temperature $72{ }^{\circ} \mathrm{C}$ and extraction time of $3 \mathrm{~h}$. The average molecular weight of CSP- 1 was $56335 \mathrm{Da}$, it was composed of L-(-)-Fucose, D-(+)-Mannose, D-glucose and mainly possessed $1 \rightarrow 2,1 \rightarrow 2,6,1 \rightarrow 4$, and $1 \rightarrow 4,6$ glycosyl linkages. The LPS-induced toxicity of THP- 1 cells was eliminated by adding to CSP-1 at $10 \mu \mathrm{g} / \mathrm{mL}$ or more. Furthermore, CSP-1 exhibited immunomodulatory properties by inhibiting ROS generation and downregulating TLR-4 mRNA, MyD88 mRNA and TRAF-6 mRNA expression in LPS-induced THP-1 cells.

Acknowledgments: This study was supported by the National Natural Science Foundation, China (81001024, 81572989). 
Author Contributions: Kehai Liu and Junwen $\mathrm{Wu}$ conceived and designed the experiments; Junwen Wu, Xuefei Zhou and Juanjuan Han performed the experiments; and Min Zhang and Yun Yao analyzed the data. All authors read and approved the final manuscript.

Conflicts of Interest: The authors declare no conflict of interest.

\section{Abbreviations}

$\begin{array}{ll}\text { CSP } & \text { Cereus sinensis Polysaccharide } \\ \text { DEAE } & \text { Diethylaminoethyl cellulose } \\ \text { GPC } & \text { Gel Permeation Chromatography } \\ \text { GS-MS } & \text { Gas Chromatography-Mass Spectrometer } \\ \text { LPS } & \text { Lipopolysaccharide } \\ \text { THP-1 cells } & \text { Human monocytic cells } \\ \text { TLR-4 } & \text { Toll-like receptor } 4 \\ \text { MyD88 } & \text { Myeloid differentiation factor 88 } \\ \text { TRAF-6 } & \text { Tumour necrosis factor receptor-associated factor-6 } \\ \text { PEG } & \text { Polyethylene glycol } \\ \text { Mn } & \text { Number-average molecular weight } \\ \text { M } & \text { Weight-average molecular weight } \\ \text { MP } & \text { Peak molecular weight } \\ \text { MZ } & \text { Z-average molecular weight } \\ \text { MZ+1 } & \text { Z+1-average molecular weight } \\ \text { MTT } & \text { 3-(4,5-dimethylthiazol-2-yl)-2,5-diphenyltetrazolium bromide } \\ \text { SD } & \text { Standard deviation } \\ \text { NF- } B \text { B } & \text { Nuclear factor kappa B } \\ \text { let-7i } & \text { Lethal-7i } \\ \text { IRAK } & \text { Interleukin receptor associated kinase } \\ \text { TAK } & \text { Transforming growth factor-activated Kinase } \\ \text { IKK } & \text { Inhibitor of nuclear factor kappa-B kinase } \\ \text { IKB } & \text { Inhibitor of nuclear factor kappa B } \\ \text { TNF- } \alpha & \text { Tumor necrosis factor- } \alpha \\ \text { IL } & \text { Interleukin } \\ \text { MAPK } & \text { Mitogen-activated protein kinase } \\ \text { EPK } & \text { Extracellular signal-regulated kinase } \\ \text { p38 } & \text { p38 mitogen-activated protein kinase } \\ \text { JNK } & \text { c-Jun N-terminal kinase } \\ \text { AP } & \text { Activator protein } \\ \text { RPMI } & \text { Roswell Park Memorial Institute } \\ \text { NIST } & \text { National Insititute of Standards and Technology } \\ & \end{array}$

\section{References}

1. Wen, S.S.; Zhao, X.; Yu, X.L.; Gao, Y.X. The progress of research on Marine Animals Polysaccharides. Chin. J. Mar. Drugs 2009, 4, 46-51.

2. Liu, J.; Willför, S.; Xu, C.L. A review of bioactive plant polysaccharides: Biological activities, functionalization, and biomedical applications. Bioact. Carbohydr. Diet. Fibre 2015, 5, 31-61. [CrossRef]

3. Faggio, C.; Pagano, M.; Dottore, A.; Genovese, G.; Morabito, M. Evaluation of anticoagulant activity of two algal polysaccharides. Nat. Prod. Res. 2016, 30, 1934-1937. [CrossRef] [PubMed]

4. Faggio, C.; Morabito, M.; Armeli, M.S.; Lo, P.G.; Pagano, M.; Genovese, G. Potential use of polysaccharides from the brown alga Undaria pinnatifida as anticoagulants. Braz. Arch. Biol. Technol. 2015, 58, 798-804. [CrossRef]

5. Jiao, H.; Shang, X.H.; Dong, Q.; Wang, S.; Liu, X.Y.; Zheng, H.; Lu, X.L. Polysaccharide constituents of three types of sea urchin shells and their anti-inflammatory activities. Mar. Drugs 2015, 13, 5882-5900. [CrossRef] [PubMed] 
6. Li, L.; Li, H.; Qian, J.Y.; He, Y.F.; Zheng, J.L.; Lu, Z.M.; Xu, Z.H.; Shi, J.S. Structural and immunological activity characterization of a polysaccharide isolated from Meretrix meretrix Linnaeus. Mar. Drugs 2016, 14, 6. [CrossRef] [PubMed]

7. Zong, A.Z.; Cao, H.Z.; Wang, F.S. Anticancer polysaccharides from natural resources: A review of recent research. Carbohydr. Polym. 2012, 90, 1395-1410. [CrossRef] [PubMed]

8. Yuan, Z.X.; Sun, M.L.; Zhao, B.; Yang, X.; Kong, H.X.; Zhang, H.Y.; Sun, L.K.; Kang, J.S. Malignant glioma cells apoptosis induced by sea anemones (Phyllodiscus semoni) venom. J. Apoplexy Nerv. Dis. 2006, 5, 594-596.

9. Tejucaa, M.; Anderluhb, G.; Serrac, M.D. Sea anemone cytolysins as toxic components of immunotoxins. Toxicon 2009, 54, 1206-1214. [CrossRef] [PubMed]

10. Subramanian, B.; Sangappellai, T.; Rajak, R.C.; Diraviam, B. Pharmacological and biomedical properties of sea anemones Paracondactylis indicus, Paracondactylis sinensis, Heteractis magnifica and Stichodactyla haddoni from East coast of India. Asian Pac. J. Trop. Med. 2011, 4, 722-726. [CrossRef]

11. Shi, W.J.; Qin, S.; Zhao, C.H.; Wu, J.P. Review of sea anemones compound and bioactivity. Mar. Sci. 2013, 37, 122-131.

12. He, R.J.; Zhao, Y.J.; Zhao, R.N.; Sun, P.L. Study on optimizing homogenate extraction processing and immune activity in vitro of polysaccharide form sea anemone. J. Zhejiang Univ. Technol. 2015, 43, 389-392.

13. Zheng, S.Z.; Pan, L.J.; Huang, F.L.; Lin, H.Z. The study on the chemical components of polysaccharides from sea anemone Zoanthus Stephensoni. Guangzhou Chem. 1991, 3, 52-56.

14. Zheng, S.Z.; Pan, L.J.; Huang, F.L.; Gong, L.H. The effects of the polysaccharides from sea anemone Zoanthus Stephenson on perfused isolated rabbit heart tissue and blood pressure of rats. Guangzhou Chem. 1991, 4, 53-57.

15. Li, Y. Species Composition and Faunastic Characteristics of the Order Actiniaria (Cnidaria: Anthozoa) in Chinese Waters. Ph.D. Thesis, Institute of Oceanology, Chinese Academy of Sciences, Qingdao, China, 2013.

16. Shi, W.J.; Zhang, C.H.; Qin, S.; Wu, J.P. Preliminarily isolation and stability analysis of cytolytic toxins from Cereus sinensis Verrill. Chin. J. Mar. Drugs 2013, 32, 14-20.

17. Zhou, X.F.; Liu, K.H.; Chen, S.S. Nutrients and non-volatile tastecompounds of Cereus sinensis. Sci. Technol. Food Ind. 2016, 37, 345-349. [CrossRef]

18. Pi, J.H.; Tan, J.; Hu, Z.D. Study on in vitro immune activity of Rosa laevigata polysaccharide. West China J. Pharm. Sci. 2014, 29, 149-151.

19. Lauriano, E.R.; Pergolizzi, S.; Capillo, G.; Kuciel, M.; Alesci, A.; Faggio, C. Immunohistochemical characterization of Toll-like receptor 2 in gut epithelial cells and macrophages of goldfish Carassius auratus fed with a high-cholesterol diet. Fish Shellfish Immunol. 2016, 59, 250-255. [CrossRef] [PubMed]

20. Lu, Y.C.; Yeh, W.C.; Ohashi, P.S. LPS/TLR4 signal transduction pathway. Cytokine 2008, 42, $145-151$. [CrossRef] [PubMed]

21. Chanput, W.; Mes, J.; Vreeburg, R.A.; Savelkoul, H.F.; Wichers, H.J. Transcription profiles of LPS-stimulated THP-1 monocytes and macrophages: A tool to study inflammation modulating effects of food-derived compounds. Food Funct. 2010, 1, 254-261. [CrossRef] [PubMed]

22. O'Neill, L.A. Therapeutic targeting of Toll-like receptors for inflammatory and infectious diseases. Curr. Opin. Pharmacol. 2003, 3, 396-403. [CrossRef]

23. Burgos-Aceves, M.A.; Cohen, A.; Smith, Y.; Faggio, C. Estrogen regulation of gene expression in the teleost fish immune system. Fish Shellfish Immunol. 2016, 58, 42-49. [CrossRef] [PubMed]

24. Sun, X.F.; Wang, H.X.; Liang, L.J.; Lu, M.L.; Gu, J.Y.; He, H.Y. Inhibition of Astragalus polysaccharide in lipopolysccharide-induced cardiomyocyte hypertrophy in rats through the TLR4/NF-kB signal transduction. Chin. Pharmacol. Bull. 2013, 29, 208-212.

25. Rocch, R.; Kimura, H.; Tzou, S.C.; Suzuki, K.; Rose, N.R.; Pinchera, A.; Ladenson, P.W.; Caturegl, P. Toll-like receptor MyD88 and Fcreceptor pathways of mast cells mediate the thyroid dysfunctions observed during nonthyroidal illness. Proc. Natl. Acad. Sci. USA 2007, 104, 6019-6024. [CrossRef] [PubMed]

26. Liu, B.; Yang, Y.; Dai, J.; Medzhitov, R.; Freudenberg, M.A.; Zhang, P.L.; Li, Z. TLR4 up-regulation at protein or gene level is pathogenic for lupus -like autoimmune disease. J. Immunol. 2006, 177, 6880-6888. [CrossRef] [PubMed]

27. Cai, W.; He, J.C.; Zhu, L.; Chen, X.; Wallenstein, S.; Striker, G.E.; Vlassara, H. Reduced oxidant stress and extended lifespan in mice exposed to a low glycotoxin diet: Association with increased AGER1 expression. Am. J. Pathol. 2007, 170, 1893-1902. [CrossRef] [PubMed] 
28. Wu, Y.; Kuang, M.; Zhou, H.; Pan, X.C. Progress of Research on TLR4 Signal Pathway and its Negative Regulation. J. Mod. Med. Health 2016, 32, 2821-2824.

29. Jia, S.J.; Niu, P.P.; Cong, J.Z.; Zhang, B.K.; Zhao, M. TLR4 signaling: A potential therapeutic target in ischemic coronary artery disease. Int. Immunopharmacol. 2014, 23, 54-59. [CrossRef] [PubMed]

30. Chen, X.M.; Splinter, P.L.; O' hara, S.P.; LaRusso, N.F. A cellular micro-RNA, let-7i, regulates Toll-like receptor 4 expression and contributes to cholangiocyte immune responses against Cryptosporidium parvum infection. J. Biol. Chem. 2007, 282, 28929-28938. [CrossRef] [PubMed]

31. Rhee, S.H.; Hwang, D. Murine Toll-like receptor 4 confers lipopolysaccharide responsiveness as determined by activation of NFKB and expression of the inducible cyclooxygenas. J. Biol. Chem. 2000, 275, 34035-34040. [CrossRef] [PubMed]

32. Takeda, K.; Akira, S. Toll-like receptors in innate immunity. Int. Immunol. 2005, 17, 1-14. [CrossRef] [PubMed]

33. Lin, S.C.; Lo, Y.C.; Wu, H. Helical assembly in the MyD88-IRAK4-IRAK2 complex in TLR/IL-1R signalling. Nature 2010, 465, 885-890. [CrossRef] [PubMed]

34. Bryant, C.E.; Symmons, M.; Gay, N.J. Toll-like receptor signalling through macromolecular protein complexes. Mol. Immunol. 2015, 63, 162-165. [CrossRef] [PubMed]

35. Bohannon, J.K.; Hernandez, A.; Enkhbaatar, P.; Adams, W.L.; Sherwood, E.R. The immunobiology of Toll-like receptor 4 agonists: From endotoxin tolerance to immunoadjuvants. Shock 2013, 40, 451-462. [CrossRef] [PubMed]

36. Frazão, J.B.; Errante, P.R.; Condino-Neto, A. Toll-like receptors' pathway disturbances are associated with increased susceptibility to infections in humans. Arch. Immunol. Ther. Exp. 2013, 61, 427-443. [CrossRef] [PubMed]

37. Chang, L.; Karin, M. Mammalian MAP kinase signalling cascades. Nature 2001, 410, 37-40. [CrossRef] [PubMed]

38. Dërmaku-Sopjani, M.; Abazi, S.; Faggio, C.; Kolgeci, J.; Sopjani, M. AMPK-sensitive cellular transport. J. Biochem. 2014, 155, 147-158. [CrossRef] [PubMed]

39. Wu, S.J.; Liaw, C.C.; Pan, S.Z.; Yang, H.C.; Ng, L.T. Phellinus linteus polysaccharides and their immunomodulatory properties in human monocytic cells. J. Funct. Food 2013, 5, 679-688. [CrossRef]

40. Baeuerle, P.A.; Henkel, T. Function and activation of NFאB in the immune system. Annu. Rev. Immunol. 1994, 12, 141-179. [CrossRef] [PubMed]

41. Shang, F.J.; Wang, J.P.; Zheng, Q.S.; Liu, X.T.; Xue, Y.S.; Li, J.; Zhao, L.Y. The relationship between reactive oxygen species-dependent activation of p38 MAPK and the expression of tumor necrosis factor- $\alpha$ in cultured cardiomyocytes. Chin. J. Cell. Mol. Immunol. 2011, 27, 7-10. 